\title{
BÜYÜK ÖLÇEKLİ MEVDUAT BANKALARININ KISA VE UZUN VADELI FAİZ ORANI RISSKI DUYARLILIKLARININ INCELENMESİ: KANTIL REGRESYON (QUANTILE REGRESSION) YÖNTEMİNE DAYALI BİR ANALİZ
}

\author{
LARGE-SCALE TURKISH DEPOSIT BANKS’ EXPOSURE TO \\ SHORT - AND LONG-TERM INTEREST RATE RISK: A QUANTILE \\ REGRESSION ANALYSIS
}

\author{
Önder BÜBERKÖKÜ
}

\section{Öz}

Günümüzde FED (Federal Reserve Bank, FED) ve ECB’nin (European Central Bank, ECB) para politikaları uygulamaları ve TCMB’nin (Türkiye Cumhuriyet Merkez Bankası, TCMB) faiz politikasına ilişkin tartışmalar faiz oranları üzerindeki belirsizliğin artması sonucu doğurmuştur. Bu çalışmada BİST’te (Borsa İstanbul, BIST) işlem gören 6 büyük mevduat bankasının kısa ve uzun vadeli faiz oranı riskine olan duyarlılıkları iki faktörlü Arbitraj Fiyatlama Modeli ile incelenmiştir. Kısa vadeli faiz oranı olarak 3 ay vadeli bankalar arası para piyasası faiz oranı, uzun vadeli faiz oranı olarak ise 10 yıl vadeli devlet tahvili faiz oranları kullanılmıştır. Model tahminlerinde kantil regresyon yönteminden yararlanılmıştır. Böylece, standart EKK (En Küçük Kareler, EKK) yöntemine göre daha etkin ve tutarlı tahminciler elde edilmiştir. Bulgular, bankaların hem kısa hem de uzun vadeli faiz oranı riskine duyarlı olduklarını ve faiz oranlarındaki artışlardan negatif bir şekilde etkilendiklerini göstermektedir. Ayrıca, bankaların uzun vadeli faiz oranları riskine olan duyarlılıklarının belirgin bir şeklide fazla olduğu anlaşılmaktadır.

Anahtar Kelimeler: Faiz oranı riski, Mevduat bankaları, Kantil regresyon

JEL Sınıflandırması: C21, G12, G21

\section{Abstract}

In this study the short - and long-term interest rate exposures of 6 large-scale Turkish deposit banks are examined using a two-factor arbitrage pricing model. As a short-term interest rate, the three-month interbank rate is used, while a 10-year government bond yield is used as a long-term interest rate. Results show that the banks

* Dr. Öğr. Üyesi, Yüzüncü Yıl Üniversitesi İşletme Fakültesi, Finans Bilim Dalı, onderbuber@gmail.com 
are exposed to both short - and long-term interest rate risk, and changes in interest rates negatively affect the banks' stock returns. However, it is also found that banks are more sensitive to long-term interest rate risk compared with short-term interest rate risk. Further, results reveal that some banks' degree of interest rate sensitivities depend on the location of their stock returns.

Keywords: Interest rate risk, Turkish deposit banks, Quantile regression

JEL Classification: C21, G12, G21

\section{I.GiRiş}

Finansal sistemin en önemli unsurlarından birini bankalar oluşturmaktadır. Bankaların bu sistem içerisindeki en temel işlevi kaynaklarının etkin dağılımının sağlanmasıdır. Bankalar bu işlevi yerine getirirken bazı önemli risklere maruz kalmaktadırlar. Bu risklerin başında ise faiz oranı riski gelmektedir (Elyasiani ve Mansur, 1998, s.536). Makro açıdan yaklaşıldığında literatürde bankaların faiz oranı riskine maruz kalmalarının nedenleri olarak bu kuruluşların faize duyarlı varlık ve yükümlülüklerinin fazlalığı, faiz oranlarının yüksek volatilitesi ve bankaların aktifi ile pasifi arasındaki vade uyumsuzluğu gibi konularının öne çıktığı görülmektedir (Papadamou ve Siriopoulos, 2014, s.46; Park ve Choi, 2011, s.135). Süreci daha mikro yaklaşımlara indirgemek gerekirse de literatürün bankaların faiz oranı riskine maruz kalmalarını daha çok durasyon gapı ile açıklamaya çalıştığ 1 ifade edilebilir (Czaja, Scholz ve Wilkens,2009, s.2; Bharati, Nanisetty ve So, 2006, s.37). Durasyon gapı faize duyarlı aktiflerin ağırlıklı ortalama süresi ile faize duyarlı pasiflerin ağırlıklı ortalama süresinin birbirinden farklı olması durumunu ifade etmektedir. Böyle bir durumda faiz oranlarındaki değişimler bankaların aktif ve pasifini farklı oranlarda etkilediğinden bankaların net nakit akışlarının bugünkü değeri de değişmektedir. Bu nedenle bankalar açısından en uygun seçeneğin aktif ve pasifin durasyonunun eşitlenmesi olduğu düşünülebilir. Fakat böyle bir yaklaşım bankaların oldukça düşük düzeyde risk üstlenmesi anlamına geldiğinden karlarının da düşük düzeylerde olmasına yol açacaktır. Bu nedenle modern yaklaşımlarda ve giderek küreselleşen bankacılık sektöründe önemli olan noktanın risk taşımamak değil taşınan riskin farkında olmak ve onu doğru yönetmek olduğu ifade edilebilir.

Son yıllarda faiz oranlarına dönük gerek yurtiçinde gerekse küresel bazda bazı önemli gelişmeler yaşanmıştır. Bu gelişmelerin başında 2007-2008 yılında ABD’de başlayıp ardından Avrupa'ya yayılan ve daha sonra diğer birçok dünya ekonomisi üzerinde de etkili olan küresel finans krizi gelmektedir. Bu kriz döneminde FED ve ECB öncelikle oldukça gevşek para politikaları uygulamışlardır. Faiz oranlarının sıfır düzeyine yaklaşması nedeniyle de bir noktadan sonra geleneksel olmayan para politikası araçları ile likiditeyi daha da artırma yoluna gitmişlerdir. Bu gelişmeler de Türkiye gibi yükselen piyasa ekonomileri üzerinde çeşitli etkilere yol açmıştır. Burada faiz oranları ile ilgili olarak dikkat çeken gelişme ise önceden beklenmeyen bir şekilde Türkiye gibi yükselen piyasa ekonomilerinin merkez bankalarının küresel finans krizinin yaşandığı bir süreçte gevşek para politikaları uygulamaları ile faiz oranlarını düşürebilmiş olmalarıdır. Bu gelişmenin Türkiye özelinde enflasyon hedeflemesine bağlı olarak oldukça düşen enflasyon oranları ile desteklenmesi ise yurtiçi faiz oranlarının tarihi düşük seviyelere inmesine yardımcı olmuştur. 
Küresel finans krizinin bu ilk etkilerinin geride bırakıldığ tışlarının Türkiye gibi yükselen piyasa ekonomileri üzerinde ne tür etkilerinin olabileceği ve TCMB'nin böyle bir ortamda uyguladığı faiz politikasının doğru bir politika olup olmadığı gibi konuların tartışıldığı görülmektedir. Bu tartışmalar da faiz oranları konusundaki belirsizliğin artmasına yol açmaktadır. Bu durum da bankacılık sektörü açısından ilave riskleri beraberinde getirebilmektedir. Bu nedenle, böyle bir konjonktürde, Türk bankacılık sektörünün yapı taşını oluşturan mevduat bankalarının faiz oranı riski duyarlılıklarının incelenmesinin önemli bir konu haline geldiği düşünülmektedir.

Literatürde faiz oranı riskinin bankalar üzerindeki etkisi genel olarak Stone (1974) tarafindan tavsiye edilen iki faktörlü Arbitraj Fiyatlama Modeli ile incelenmektedir. Bu model özü itibariyle faiz oranı riskini bankaların hisse senedi fiyatları ile ilişkilendirmektedir. Literatürde, faiz oranlarındaki değişimlerin çeşitli kanallar üzerinden banka hisse senedi fiyatları üzerinde etkili olabileceği ifade edilmektedir. Örneğin, Bernanke ve Kurter (2005, s.1253) bu konuda üç farklı kanaldan bahsetmektedir. Birinci kanala göre, diğer unsurlar sabit kalmak şartıyla, faiz oranlarındaki artışlar bankaların faiz harcamalarının artmasına yol açabilmektedir. Bu da bankaların ileriki dönemlerde dağıtacağı kar paylarının azalmasını beraberinde getirebileceğinden faiz oranlarındaki artışlar banka hisselerini negatif yönde etkileyebilmektedir. İkinci kanala göre ise faiz oranlarındaki artışlar ileriki dönemlerde reel faiz oranlarının artacağı yönünde bir beklentinin oluşmasına sebep olabilmektedir. Bu durum da ileride elde edilecek nominal getirilerin bugünkü değerlerinin azalması anlamına geldiğinden banka hisseleri bundan negatif bir şekilde etkilenebilecektir. Üçüncü kanala göre ise merkez bankalarının faiz oranlarını artırdığı dönemlerde yatırımcılar risk-getiri beklentilerine bağlı olarak portföylerini artan faiz oranları lehine yeniden dizayn etme eğilimi içerisinde olabilmektedir. Bu durum da bankaların piyasa değerinin negatif bir şekilde etkilenmesine yol açabilmektedir.

$\mathrm{Bu}$ yaklaşıma ilaveten literatürde süreci kredi kanalını dikkate alarak açıklamaya çalışan çalışmalar da bulunmaktadır. Çünkü faiz oranlarındaki artışlar bankalardan kredi kullanan reel sektör firmalarının nakit akışlarında bozulmaya yol açabilmektedir. Nakit akışları bozulan şirketlerin yükümlülüklerini aksatması da bankaların nakit girişlerinin azalmasına sebep olabilmektedir. Piyasanın bu durumu fiyatlaması ise banka hisselerinin değer kaybetmesine yol açabilmektedir (Kasman, Vardar ve Tunç, 2011, s. 1332). Ayrıca, artan faiz oranları risk düzeyi düşük kredi kullanıcılarının kredi talebini azaltırken risk düzeyi yüksek kredi kullanıcılarının kredi talebini artırabilmektedir. Bu da bankaların ters seçim (adverse selection) olasılığını artırarak banka hisselerinin değer kaybetmesine yol açabilmektedir (Papadamou ve Siriopoulos, 2014, s.47).

Fakat faiz oranı riski ile banka hisseleri arasındaki teorik ilişkiyi açıklamaya çalışan bu yaklaşımlara rağmen daha öncede belirtildiği gibi literatürün bankaların faiz oranı riskine maruz kalmalarını ağırlıklı olarak aktif ile pasif arasındaki vade uyumsuzluğu ile açıklamaya çalıştığı görülmektedir (Bharati, Nanisetty ve So, 2006, s.37; Akella ve Greenbaum, 1992, s. 28; Korkeamaki, 2011, s.813). Bu durumun teorik altyapısı da şu şekilde açıklanabilir: Bankalar daha çok kısa vadeli kaynaklara sahip olmakta ve bu kaynakları uzun vadeli krediler olarak değerlendirmektedir. Genel bir ifadeyle bir bankanın hisse senedi fiyatının bankanın aktif ve (özsermaye hariç) pasifinin piyasa değeri arasındaki farka eşit olduğu düşünüldüğünde aktif ve pasifteki kalemlerin değerlerinin faiz oranlarındaki 
değişime olan duyarlılık derecelerine bağlı olarak bankaların hisse senedi fiyatlarının da faiz oranları ile birlikte değişebileceği ifade edilebilir (Bharati, Nanisetty ve So, 2006, s.37). Faiz oranlarındaki bu değişimlerin bankalar üzerinde ne kadar etkili olacağını ise durasyon gapı ve konveksite gibi faiz oranı riski göstergeleri ile bankaların risk yönetim uygulamalarının etkinlik düzeyi belirleyecektir (Papadamou ve Siriopoulos, 2014, s.47).

Literatürde faiz oranı riskinin bankalar üzerindeki etkisini inceleyen çeşitli çalışmalar bulunmaktadır. Öncelikle, gelişmiş ülke ekonomileri üzerine yapılan çalışmalara bakıldığında Faff ve Howard (1992) Avustralya bankalarının kısa ve uzun vadeli faiz oranı riski duyarlılıklarını inceledikleri çalışmalarında bankaların sadece uzun vadeli faiz oranı riskine duyarlı oldukları sonucuna ulaşmışlardır. Ekella ve Greenbaum (1992) ABD bankalarını inceledikleri çalışmalarında bankaların faiz oranlarındaki beklenmeyen değişimlere duyarlı oldukları ve faiz oranlarındaki artışların banka hisselerini negatif yönde etkilediği sonucuna ulaşmışlardır. Elyasiani ve Mansur (1998) da ABD bankalarını inceledikleri çalışmalarında uzun vadeli faiz oranlarındaki artışların ABD bankalarının piyasa değerinin azalmasına yol açtığı sonucuna ulaşmışlardır. Faff ve Howard (1999) Avustralya için büyük ve küçük ölçekli bankalar ile banka-dışı finansal şirketlerin kısa, orta ve uzun vadeli faiz oranı riski duyarlılıklarını inceledikleri çalışmalarında büyük ölçekli bankaların ve finansal kuruluşların sadece uzun vadeli faiz oranı riskine duyarlı oldukları, küçük ölçekli bankaların ise çalışma kapsamındaki hiçbir faiz oranı riskine duyarlı olmadıkları sonucuna ulaşmışlardır. Ayrıca, finans sektörünün giderek daha liberal hale gelmesinin finansal kuruluşların faiz oranı riskine olan duyarlılığını arttırdığını da belirtmişlerdir. Czaja, Scholz ve Wilkens (2009) Almanya’yı inceledikleri çalışmalarında bankacılık ve sigorta sektörü hisselerinin getiri eğrisindeki değişimlerden etkilendiği sonucuna ulaşmışlardır. Ferrer ve Gonzalez (2010) İspanya için çeşitli sektörel hisse senedi endekslerini inceledikleri çalışmalarında bankacılık sektörünün hem kısa hem de uzun vadeli faiz oranı riskine en duyarlı sektörlerden biri olduğu sonucuna ulaşmışlardır. Dinenis ve Staikouras (2010) ise İngiltere'de faaliyet gösteren banka, sigorta, yatırım ortaklıkları, gayrimenkul yatırım ortaklıkları ve diğer finansal kuruluşların faiz oranı riskine duyarlılıklarını inceledikleri çalışmalarında faiz oranları ile belirtilen finansal kuruluşların hisse senedi getirileri arasında negatif ve istatistiki olarak anlamlı bir ilişki olduğu sonucuna ulaşmışlardır. Korkeamaki (2011) Euro’nun Avrupa ülkelerinin faiz oranı riski duyarlılığına olan etkisini incelediği çalışmasında Euro öncesinde ülke hisse senedi endekslerinin faiz oranlarındaki artışlardan negatif bir şekilde etkilendiği, Euro'ya geçiş ile birlikte ise bu negatif etkinin ortadan kalktığ 1 sonucuna ulaşmıştır. Papadamou ve Siriopoulos (2014) İngiltere merkez bankasının bağımsızlığının İngiliz banka ve sigorta şirketlerinin faiz oranı riski duyarlılığına olan etkisini inceledikleri çalışmalarında merkez bankasının daha bağımsız hale gelmesinin ve şeffaflığın artmasının finansal kuruluşların faiz oranı riskine olan duyarlılığını azalttığı sonucuna ulaşmıştır.

Gelişen piyasa ekonomileri ile ilgili çalışmalara bakıldığında ise Aggarwal, Jeon ve Zhao (2006) G.Kore bankalarını inceledikleri çalışmalarında bankacılık sektörünün giderek daha liberal hale gelmesinin sektörün faiz oranı riskine olan duyarlılığını azalttığı sonucuna ulaşmışlardır. Saha, Subramma, Basu ve Mishra (2009) Hindistan ticari bankalarını inceledikleri çalışmalarında faiz oranı riskinin banka hisseleri üzerinde oldukça etkili olduğu sonucuna ulaşmışlardır. Mouna ve Anis (2012) Tunus bankalarını inceledikleri çalışmalarında banka hisselerinin faiz oranlarındaki değişimlerden 
etkilenmediği fakat uzun vadeli faiz oranlarının volatilitesinin bankaların hisse senedi volatilitesi üzerinde önemli bir etkisi olduğu sonucuna ulaşmışlardır. Sukcharoensin (2013) Tayvan'da faaliyet gösteren bankaları incelediği çalışmasında büyük ölçekli bankaların faiz oranı artışından pozitif, küçük ve etkin olmayan bankaların ise negatif yönde etkilendiği sonucuna ulaşmıştır.

Türkiye üzerine yapılan çalışmalara gelince, öncelikle literatürde bu konuyla ilgili sadece iki çalışmaya ulaşılabilmiştir. Bu çalışmaların ilkinde Kasman, Vardar ve Tunç (2011) faiz oranı ve döviz kuru riskinin Türk bankalarının hisse senedi getirileri üzerindeki etkisini incelemişlerdir. Faiz oranı riskini temsilen gösterge tahvil faizini kullandıkları çalışmalarında inceleme kapsamındaki 14 bankadan sadece 6 tanesinin faiz oranlarındaki değişimlerden etkilendiği; faiz oranı volatilitesinin ise tüm hisse senedi getirilerinin volatilitesi üzerinde etkili olduğu sonucuna ulaşmışlardır. Diğer çalışmada ise Özün ve Çifter (2006) İMKB bankacılık endeksini dikkate aldıkları çalışmalarında faiz oranlarındaki değişimlerin bankacılık endeksi getirileri üzerinde oldukça etkili olduğu sonucuna ulaşmışlardır.

$\mathrm{Bu}$ çalışmanın amacı BIST’te işlem gören 6 büyük mevduat bankasının kısa ve uzun vadeli faiz oranı riskine duyarlı olup olmadıklarının kantil regresyon yöntemi ile incelenmesidir. Çalışmanın literatüre katkısı şu şekilde ifade edilebilir: Öncelikle bu çalışmada diğer çalışmaların genelinden farklı olarak EKK yönteminden değil Koenker ve Bassett (1978) tarafından geliştirilen kantil regresyon yönteminden yararlanılmıştır. Bunun bazı nedenleri bulunmaktadır. Öncelikle, serilerin normal dağılıma uymadığı ve sapan değerlerin bulunduğu durumlarda EKK tahmin sonuçlarının güvenilirliği azalmaktadır. Ayrıca, EKK yöntemi bağımlı değişkenin şartlı dağılımının sadece ortalama bölgesine odaklanmaktadır. Bu nedenle de incelenen dönem için değişkenler arasındaki ortalama ilişkiyi ortaya koyabilmektedir. Halbuki bağımlı değişkenin çarpık bir dağılım sergilemesi durumunda şartlı dağılımın orta bölgesinin serinin dağılımının bütününü temsil etmesi zorlaşmaktadır. Kantil regresyon yöntemi ise modelin hata terimlerinin mutlak değerlerinin asimetrik olarak ağırlıklandırılmasına dayandığından sapan değerlere karşı dirençlidir (Kang ve Liu, 2014, s.358). Ayrıca, bu yöntem normal dağılmama durumunda da tutarlı sonuçlar vermektedir. Dahası, bu yöntem yarı-parametrik (semi-parametric) bir yöntem olduğundan hata terimlerinin dağılımı konusunda herhangi bir varsayımda bulunulmasına da gerek olmamaktadır. Bu nedenlerle de bu yöntem EKK yöntemine göre daha etkin ve tutarlı sonuçlar sunabilmektedir (Chevapatrakul, 2015, s.3). İkinci olarak, bilindiği gibi, son yıllarda faiz oranlarını ve finans sektörünü etkileyen oldukça önemli gelişmeler yaşanmıştır. Daha önce de belirtildiği gibi, bu gelişmelere örnek olarak 2007-2008 küresel finans krizi, FED ve ECB gibi merkez bankalarının geleneksel olmayan para politikaları uygulamaları, küresel kriz döneminde yurtiçi faiz oranlarının tarihi düşük seviyeleri inmesi, bankacilık sektörünün aktifinde menkul kıymetlerin yerine giderek kredilerin, pasifinde ise yurtdışı fonların ağırlığının artması ve daha güncel olarak ise FED’in faiz artışlarının olası etkilerinin neler olabileceği yönündeki tartışmalar ile TCMB’nin faiz politikasına ilişkin tartışmalar gösterilebilir. Bu vb. gelişmeler de banka hisselerini kimi zaman pozitif kimi zaman da negatif yönde etkilemektedir. Dolayısıyla, böyle bir konjonktürde faiz oranı riskinin bankalar üzerindeki etkisi incelenirken banka hisselerinin farklı dağılım bölgelerine odaklanılması önemli bir konu haline gelmektedir. Nitekim kantil regresyon yöntemi değişkenler arasındaki ilişkiyi incelerken bağımlı değişkenin (bu çalışma özelinde banka hisselerinin) dağılımının farklı bölgelerine 
odaklanabilmektedir (Vu, Holmes, Lim ve Tuyen Tran, 2014, s.443; Chevapatrakul, 2015, s.2; Kang ve Liu, 2014, s.358; Hammoudeh, Nguyen ve Sausa, 2014, s.202; Chen, Kaun ve Lin, 2007, s.105). Böyle bir yaklaşım da farklı dağılım bölgeleri dikkate alınarak faiz oranı riskinin bankalar üzerindeki etkisinin incelenmesine imkan vermektedir (Chevapatrakul, 2014, s.126; Chevapatrakul, 2015, s.2). Bu özelliklerinden dolayı da bu yöntemin güncel finansal yazında giderek daha yaygın bir şekilde kullanılmaya başlandığı görülmektedir (Chuang, Kuan ve Lin ,2009; Lee ve Li,2012; Baur, 2013; Ciner, 2015). Bu kapsamda literatüre bakıldığında kantil regresyon yöntemi uygulanırken genelde bağımlı değişkenin şartlı dağılımının üç farklı bölgeye ayrıldığı görülmektedir. Bu bölgeler düşük kantil bölgesi, orta kantil bölgesi ve yüksek kantil bölgesi olarak tanımlanabilir. Tüm dağılımın 0.05 'lik kantillere bölündüğü düşünüldüğünde 0.05 ile 0.40 . kantiller arası düşük, 0.45 ile 0.60. kantiller arası orta, 0.65 ile 0.95. kantiller arası ise yüksek kantil bölgesi olarak tanımlanmaktadır (Lee ve Zheng, 2011, s.1918). Bu noktanın konumuz açısından önemi ise şudur: Farklı dağılım bölgeleri dikkate alındığında değiş̧kenler arasındaki ilişkinin istikrarlı bir seyir izleyip izlemediği anlaşılabilmektedir (Chevapatrakul, 2015, s.2; Chevapatrakul, 2014, s.126). Üçüncü olarak, bu çalışmada hem kısa hem uzun vadeli faiz oranı riski dikkate alınmıştır. Son olarak ise, konunun önemine rağmen, literatür kısmında da belirtildiği gibi faiz oranı riskinin Türk bankaları üzerindeki etkisini inceleyen oldukça sınırlı sayıda çalışma olduğu görülmektedir.

Çalışma dört bölümden oluşmaktadır. İkinci bölümde veri ve metodoloji açıklanmakta üçüncü bölümde bulgular tartışılmakta dördüncü bölümde ise sonuç kısmı yer almaktadır.

\section{VERi ve METODOLOJi}

\subsection{Veri}

Çalışma, Ocak 2006 ile Şubat 2014 dönemini kapsamakta ve aylık verilerden oluşmaktadır. Çalışmanın başlangıç yılının seçimi verilere ulaşabilirlik özelliğinden kaynaklanmaktadır. Daha açık bir ifadeyle, hisse senedi fiyatları ve kısa vadeli faiz oranları için daha önceki dönemlere ait veriler bulunmasına rağmen 10 yıl vadeli devlet tahvili verilerinin 2006 yılı ile başlaması nedeniyle çalışma da 2006 yılından başlamaktadır. Fakat Halkbankası için başlangıç tarihi bankanın halka açılma tarihi olan Mayıs 2007'dir. Çalışmada büyük ölçekli bankalar olarak BIST’te işlem gören AKBANK, Halk Bankası, Garanti Bankası, İş Bankası, Yapı Kredi Bankası ve Vakıfbank incelenmiştir. Bu bankaları temsilen çalışmada sırasıyla AKBNK, HLKBNK, GRNBNK, ISBNK, YPKBNK ve VKFBNK ifadeleri kullanılmıştır. Kısa vadeli faiz oranı riski için 3 ay vadeli bankalar arası para piyasası faiz oranları, uzun vadeli faiz oranı riski içinse 10 yıl vadeli devlet tahvili faiz oranlarından yararlanılmıştır. Piyasa getirisini temsilen BIST100 endeksi kullanılmıştır. Hisse senedi ve kısa vadeli faiz oranı verileri FINNET’ten, uzun vadeli faiz oranı verisi ise Eurostat'tan temin edilmiştir.

\subsection{Metodoloji}

Çalışmada literatürle uyumlu bir şekilde Stone (1974) tarafından tavsiye edilen iki faktörlü Arbitraj Fiyatlama modeli kullanılmıştır. Bu model Denklem (1)'deki gibi ifade edilebilir: 


$$
R_{i t}=\phi_{i}+\beta_{1 i} R_{m t}+\beta_{2 i} \Delta I_{t}+\eta_{i t}(1)
$$

Burada, $R_{i t} i$ bankasının hisse senedi getirilerini, $R_{m} t$ piyasa getirisini, $\Delta I_{t}$ faiz oranlarındaki değişimi, $\phi_{i}$ sabit terimi, $\eta_{i t}$ hata terimini, $\beta_{1 i}$ hisse senetlerinin sistematik riskini, $\beta_{2 i}$ ise faiz oranı riskini ifade etmektedir. Daha önce belirtilen teorik nedenlerden hareketle $\beta_{2 i}$ katsayısının negatif çıkması beklenmektedir.

Çalışmada, literatürle uyumlu bir şekilde $R_{\text {it }}$ ve $R_{m}$ değişkenleri hisse senedi fiyatlarındaki yüzde değişim olarak tanımlanmıştır. Bir diğer ifade ile $P_{t}$ hisse senetlerinin $t$ zamanındaki fiyatını göstermek üzere $R_{i t}$ ve $R_{m t}$ sirasiyla $R_{i t}=\left(P_{t}-P_{t-1}\right) / P_{t-1}$ ve $R_{m t}=\left(P_{m t}-P_{m t-1}\right) / P_{m t-1}$ $R_{m t}=\left(P_{m t}-P_{m t-1}\right) / P_{m t-1}$ şeklinde hesaplanmıştır. Faiz oranları ise zaten yüzde cinsinden ifade edildiğinden faiz oranlarındaki değişim, faiz oranlarının bir önceki döneme göre farkı alınarak hesaplanmıştır $\left(\Delta I_{t}=I_{t}-I_{t-1}\right)$.

Fakat Denklem (1)'de gösterilen model literatürde eleştirilmektedir. Çünkü, diğerlerinin yanı sıra Choi ve Prasad’ın $\left(1995\right.$, s.78) belirttiği gibi burada, $R_{m}$ t piyasa riskini temsil eden bir değişken olarak zaten içerisinde faiz oranı riskini barındırmaktadır. Dolayısıyla, denklemde ayrıca faiz oranı riskini temsilen $\Delta I_{t}$ değişkeninin de bulunması elde edilecek sonuçların güvenilirliğini azaltabilmektedir. Ayrıca, Denklem (1)'in kullanılması durumunda $\Delta I_{t}$ değişkeninin anlamlı çıkmaması bankaların faiz oranı riskini duyarlı olmadıkları gibi bir sonuca ulaşılmasına yol açabilmektedir. Halbuki, bunun nedenlerinden biri bankaların faiz oranı riskine duyarlı olmamaları değil piyasanın (yani $R_{m}$ değişkeninin) faiz oranı riski duyarlılığının bankaların faiz oranı riski duyarlılıklarından fazla olmasi olabilir (Aysun ve Guldi, 2011, s.324). Bu sorunlara ilk defa Choi ve Prasad (1995, s.78) dikkat çekerek çözüm olarak $R_{m}$ t'nin bağımlı $\Delta I_{t}$ 'nin ise bağımsız değişken olacağı bir model kurulup öncelikle bu modelin tahmin edilmesini, ardından bu modelden elde edilen kalıntıların Denklem(1)'de gösterilen $R_{m} t$ yerine kullanılmasını tavsiye etmişlerdir. Bu hususu ekonometrik olarak ifade etmek gerekirse öncelikle aşağıda gösterilen Denklem (2) tahmin edilmiş:

$$
R_{m t}=\phi_{i}+\beta_{3 i} \Delta I_{t}+\varepsilon_{i t}(2)
$$

Ardından, buradan elde edilen ve $R_{m t}-\left(\phi_{i}+\beta_{3 i} \Delta I_{t}\right)$ değerine eşit olan $\overline{R_{m t}} \overline{R_{m t}}$ değeri faiz oranı riskinden arındırılmış piyasa riskini temsil edecek şekilde Denklem (1)'deki $R_{m t} R_{m t}$ değeri yerine yazılarak aşağıda gösterilen Denklem (3)'e ulaşılmıştır.

$$
R_{\text {it }}=\phi_{i}+\beta_{1 i} \overline{R_{m t}}+\beta_{2 i} \Delta I_{t}+\eta_{i t}(3)
$$

Nitekim bu dönüşüm sayesinde artık bankaların göreli faiz oranı riski duyarlıllğı değil toplam faiz oranı riski duyarlılığı hesaplanmış olmaktadır. Ayrıca, literatüre bakıldığında da bu uygulamanın yaygın olarak kullanıldığı görülmektedir (Sweeney ve Warga, 1986; Park ve Choi, 2011; Aysun ve Guldi, 2011).

Fakat Denklem (3)'te gösterilen model literatürde genelde EKK ile tahmin edilmektedir. Bu çalışmada ise daha önce belirtilen gerekçelere bağlı olarak kantil regresyon yönteminden yararlanılmıştır. Bu kapsamda Denklem (3)'teki model kantil regresyon yöntemi cinsinden Denklem (4)'te gösterildiği gibi ifade edilebilir: 


$$
q_{\mathrm{t}}\left(R_{\mathrm{it}} \mid \overline{R_{m t}}, \Delta I_{\mathrm{t}}\right)=\phi_{\tau}+\beta_{\tau} \overline{R_{m t}}+\gamma_{\tau} \Delta I_{\mathrm{t}}+\eta_{\tau i}(4)
$$

Burada, $q_{t}$ hisse senedi getirilerinin şartlı kantil fonksiyonunu; $\tau$, 0 ile 1 arasında değişen kantilleri; $\phi_{\tau}, \eta_{\tau}, \beta_{\tau}$ ve $\gamma_{\tau}$ ise farkl $\tau$ değerleri için tahmin edilen sabit terim, hata terimi, piyasa riski ve faiz oranı riski parametrelerini göstermektedir. Bu parametreler ise Denklem (5)'te gösterilen modelin liner programlama yöntemi kullanılarak minimize edilmesi ile tahmin edilmektedir:

$$
\min _{\phi_{\tau} \beta_{\tau} \gamma_{\tau}} \sum_{t=1}^{\tau} P_{\tau}\left(R_{i t}-\phi_{\tau}-\beta_{\tau} \overline{R_{m t}}-\gamma_{\tau} \Delta I_{t}\right)
$$

Burada $P_{\tau}$ kontrol fonksiyonunu (check function) ifade etmektedir.

\section{BULGULAR}

Çalışmada öncelikle serilerin durağanlık özellikleri incelenmiştir. Bu amaçla trendli (C\&T) ve trendsiz (C) model formları kullanılarak ADF (Augmented Dickey Fuller) ve KPSS (Kwiatkowski, Phillips, Schmidt ve Shin) birim kök testleri uygulanmıştır. Tablo l'de sunulan bulgular çalışma kapsamındaki tüm serilerin her durumda durağan olduklarına işaret etmektedir.

Tablo I. ADF ve KPSS Birim Kök Testi Sonuçları

\begin{tabular}{lllll}
\hline Değişkenler & ADF & & KPSS \\
& C C\&T & & \\
\hline AKBNK & $-11.409^{*}(0.000)$ & $-11.383^{*}(0.000)$ & 0.0982 & 0.0644 \\
GRNBNK & $-10.288^{*}(0.000)$ & $-10.255^{*}(0.000)$ & 0.1122 & 0.0593 \\
ISBNK & $-9.5720^{*}(0.000)$ & $-9.5229^{*}(0.000)$ & 0.0863 & 0.0842 \\
YPKBNK & $-10.960^{*}(0.000)$ & $-10.923^{*}(0.000)$ & 0.0916 & 0.0559 \\
VKFBNK & $-10.063^{*}(0.000)$ & $-10.010^{*}(0.000)$ & 0.0637 & 0.0639 \\
HLKBNK & $-9.7250^{*}(0.000)$ & $-9.6990^{*}(0.000)$ & 0.1207 & 0.0969 \\
Kisa vadeli faiz oranları & $-9.8750^{*}(0.000)$ & $-9.8413^{*}(0.000)$ & 0.1219 & 0.1002 \\
Uzun vadeli faiz oranları & $-4.8814^{*}(0.000)$ & $-4.8712^{*}(0.000)$ & 0.1065 & 0.1055 \\
BIST100 & $-9.8308^{*}(0.000)$ & $-9.7762^{*}(0.000)$ & 0.0678 & 0.0679 \\
\hline
\end{tabular}

*, **, sırasıyla \%5 ve \%10 anlamlllık düzeyini göstermektedir. ADF testi için verilen değerler t istatistikleridir. Parantez içindeki değerler olasıllk değerleridir. KPSS testi için verilen değerler LM test istatistiği değerleridir.

Serilerin durağanlık özelikleri belirlendikten sonra literatürde yaygın bir kullanım alanı olması nedeniyle çalışmada öncelikle Denklem (3)'te gösterilen model EKK ile tahmin edilmiştir. Elde edilen bulgular Tablo 2'de sunulmuştur. 
Tablo 2. Faiz Oranı Riski için EKK Tahmin Sonuçları

\begin{tabular}{|c|c|c|c|c|c|c|c|}
\hline \multicolumn{8}{|c|}{ Kısa vadeli faiz oranı riski } \\
\hline & $\phi$ & $\beta_{1}$ & $\beta_{2}$ & LM ist. & White testi & F ist. & $\mathrm{R}^{2}$ \\
\hline AKBNK & 0.865 & $1.229^{*}$ & $-2.339^{*}$ & $0.041^{\star}$ & $0.024^{*}$ & $0.000^{*}$ & 0.714 \\
\hline GRNBNK & $1.502^{*}$ & $1.365^{\star}$ & $-3.521^{*}$ & 0.165 & $0.000^{*}$ & $0.000^{*}$ & 0.862 \\
\hline HLKBNK & $0.971^{\star *}$ & $1.258^{\star}$ & $-6.114^{*}$ & $0.000^{*}$ & $0.092^{\star *}$ & $0.000^{*}$ & 0.692 \\
\hline ISBNK & 0.456 & $1.138^{*}$ & $-3.309^{*}$ & 0.367 & 0.144 & $0.000^{*}$ & 0.811 \\
\hline VKFBNK & 0.898 & $1.474^{*}$ & $-3.838^{*}$ & 0.175 & $0.004^{*}$ & $0.000^{*}$ & 0.814 \\
\hline YPKBNK & $1.058^{*}$ & $1.194^{*}$ & $-3.182^{*}$ & $0.001^{*}$ & 0.396 & $0.000^{*}$ & 0.735 \\
\hline \multicolumn{8}{|c|}{ Uzun vadeli faiz oranı riski } \\
\hline AKBNK & 0.782 & $1.215^{\star}$ & $-4.257^{\star}$ & $0.036^{*}$ & $0.045^{\star}$ & $0.000^{*}$ & 0.712 \\
\hline GRNBNK & $1.430^{*}$ & $1.386^{*}$ & $-5.040^{*}$ & 0.111 & $0.000^{*}$ & $0.000^{*}$ & 0.860 \\
\hline HLKBNK & $0.978^{\star *}$ & $1.266^{*}$ & $-6.016^{*}$ & $0.000^{*}$ & $0.096^{\star *}$ & $0.000^{*}$ & 0.691 \\
\hline ISBNK & 0.393 & $1.151^{\star}$ & $-4.631^{*}$ & 0.351 & $0.016^{\star}$ & $0.000^{*}$ & 0.805 \\
\hline VKFBNK & 0.818 & $1.493^{*}$ & $-5.544^{*}$ & 0.173 & $0.002^{*}$ & $0.000^{*}$ & 0.812 \\
\hline YPKBNK & $0.991^{\star *}$ & $1.196^{\star}$ & $-4.783^{\star}$ & $0.010^{*}$ & 0.437 & $0.000^{*}$ & 0.734 \\
\hline \multicolumn{8}{|c|}{$\begin{array}{l}\text { ***, sırasıyla \% } 5 \text { ve \%10 anlamllık düzeyini göstermektedir. Modelde otokorelasyon sorunu olup olmadığı Breusch-Godfrey LM } \\
\text { testi ile incelenmiştir. LM testi hem birinci hem ikinci sıra otokorelasyon için uygulanmıştır. Değişen varyans sorunun tespitinde } \\
\text { White (1980) testinden yararlanılmıştır. Sadece otokorelasyon sorunu olduğunda modele AR(p) değerleri eklenmiştir. Sadece de- } \\
\text { ğişen varyans sorununun olduğu durumlarda model White değişen varyansa karşı dirençli standart hatalar dikkate alınarak tah- } \\
\text { min edilmiștir. Hem otokorelasyon hem de değişen varyans sorunlarının olduğu durumda ise Newey-West (1987) tahmincisi kul- } \\
\text { lanılmıştır. LM, White ve F testleri için verilen değerler olasllık değerleridir. F testi sonuçları model anlamlllğı̆nı göstermektedir. }\end{array}$} \\
\hline
\end{tabular}

Öncelikle kısa vadeli faiz oranı riski sonuçlarına bakıldığında tüm bankalar için faiz oranı riski parametresinin negatif ve istatistikî olarak anlamlı olduğu görülmektedir. Dolayısıyla kısa vadeli faiz oranlarındaki artışların bu bankaların piyasa değerlerinin azalmasına yol açtığı ifade edilebilir. Ayrıca, kısa vadeli faiz oranı artışından en çok etkilenen bankanın HLKBNK (-6.11) en az etkilenen bankanın ise AKBNK (-2.34) olduğu anlaşılmaktadır. Uzun vadeli faiz oranı riskine bakıldığında da tüm bankalar için katsayının yine negatif ve istatistikî olarak anlamlı olduğu görülmektedir. Ayrıca, uzun vadeli faiz riskine en çok maruz kalan bankanın yine HLKBNK (-6.02), en az maruz kalan bankanın ise yine AKBNK (-4.26) olduğu ifade edilebilir. Dahası, HLKBNK hariç diğer tüm bankaların uzun vadeli faiz oranı riski parametresinin kısa vadeli faiz oranı riski parametresinden belirgin bir şekilde mutlak değerce fazla olduğu anlaşılmaktadır. Ayrıca, faiz oranı riskinden arındırılmış beta katsayıları da beklenildiği gibi her durumda pozitif ve istatistiki olarak anlamlı çıkmakta ve genel olarak 1'in biraz üzerinde değerler almaktadır. Bu kapsamda, kısaca ifade etmek gerekirse, bulgular inceleme kapsamındaki tüm bankaların hem kısa hem de uzun vadeli faiz oranı riskine maruz kaldıklarına, faiz oranındaki artışların tüm banka hisselerini negatif yönde etkilediğine ve uzun vadeli faiz oranı riskinin etkilerinin daha büyük olduğuna işaret etmektedir.

Kantil regresyon sonuçlarına gelince, bu analize dayalı sonuçlar Tablo 3 ve $4^{\prime}$ te sunulmuştur ${ }^{1}$. Öncelikle kısa vadeli faiz oranı sonuçlarına bakıldığında her bir banka için incelenen toplam 19 farklı

1 Sadelik sağlamak amacıyla tablolarda beta katsayısına ilişkin sonuçlara yer verilmemiştir. Fakat, beta katsayıları her durumda pozitif ve istatistiki olarak anlamlı çıkmaktadır. Yazardan talep edilmesi halinde bu sonuçlara da ulaşlabilir. 
kantil değerinin tamamında faiz oranı riski katsayısının sürekli bir şekilde negatif değerler aldığı görülmektedir. Dolayısıyla, banka hisselerinin dağılımının hangi bölgesine odaklanılırsa odaklanılsın bankaların kısa vadeli faiz oranlarındaki artıştan negatif bir şekilde etkilendiği anlaşılmaktadır. Katsayı anlamlılıklarına gelince neredeyse her durumda kısa vadeli faiz oranı riski katsayısının istatistiki olarak anlamlı olduğu görülmektedir ${ }^{2}$. Ayrıca, her üç kantil bölgesinde de en yüksek kısa vadeli faiz oranı riskini taşıyan banka yine HLKBNK olurken en düşük kısa vadeli faiz oranı riskini taşıyan banka yine AKBNK olmaktadır.

Uzun vadeli faiz oranı riski duyarlılı̆ına gelince, her durumda bankaların uzun vadeli faiz oranı riskine de maruz kaldıkları anlaşılmaktadır. Ayrıca, her durumda katsayılar yine negatif ve istatistiki olarak anlamlı çıkmaktadır. Dolayısıyla, banka hisselerinin dağılımının hangi bölgesine odaklanılırsa odaklanılsın uzun vadeli faiz oranlarındaki artışların da banka hisselerini negatif bir şekilde etkilediği anlaşılmaktadır. Ayrıca, genel olarak her üç kantil gölgesinde de (HLKBNK hariç) uzun vadeli faiz oranı riski parametrelerinin aldığı değerlerin kısa vadeli faiz oranı riski parametrelerinin aldığı değerlerden belirgin bir şekilde mutlak değer olarak daha büyük olduğu görülmektedir. Dahası, her üç kantil bölgesinde de genel olarak uzun vadeli faiz oranlarındaki değişimlerden en çok HLKBNK’nin en az ise AKBNK’nin etkilendiği anlaşılmaktadır.

Tablo 3. Kısa Vadeli Faiz Oranı Riski için Kantil Regresyon Sonuçları

\begin{tabular}{|c|c|c|c|c|c|c|}
\hline$\tau$ & AKBNK & ISBNK & YPKBNK & GRNBNK & HLKBNK & VKFBNK \\
\hline 0.05 & $-2.617^{\star}(0.00)$ & $-2.274^{\star}(0.00)$ & $-2.267^{\star}(0.03)$ & $-3.087^{\star}(0.00)$ & $-4.411^{*}(0.00)$ & $-3.216^{\star}(0.00)$ \\
\hline 0.10 & $-1.572(0.35)$ & $-2.478^{\star}(0.00)$ & $-3.427^{\star}(0.00)$ & $-3.082^{*}(0.00)$ & $-6.078^{\star}(0.00)$ & $-2.733^{\star}(0.00)$ \\
\hline 0.15 & $-2.401^{\star}(0.00)$ & $-3.113^{\star}(0.00)$ & $-3.092^{\star}(0.00)$ & $-3.19^{*}(0.00)$ & $-5.124^{\star}(0.00)$ & $-4.245^{\star}(0.00)$ \\
\hline 0.20 & $-1.841^{\star}(0.02)$ & $-3.082^{\star}(0.00)$ & $-3.001^{\star}(0.00)$ & $-3.156^{\star}(0.00)$ & $-5.054^{\star}(0.00)$ & $-4.232^{\star}(0.00)$ \\
\hline 0.25 & $-2.018^{*}(0.00)$ & $-3.127^{\star}(0.00)$ & $-2.678^{*}(0.00)$ & $-3.411^{\star}(0.00)$ & $-5.088^{*}(0.00)$ & $-4.058^{*}(0.00)$ \\
\hline 0.30 & $-1.550^{\star}(0.00)$ & $-3.188^{\star}(0.00)$ & $-2.863^{\star}(0.01)$ & $-3.531^{\star}(0.00)$ & $-4.867^{\star}(0.00)$ & $-3.888^{\star}(0.00)$ \\
\hline 0.35 & $-1.600^{*}(0.00)$ & $-3.248^{\star}(0.00)$ & $-3.094^{\star}(0.01)$ & $-3.756^{\star}(0.00)$ & $-6.622^{\star}(0.00)$ & $-3.695^{\star}(0.00)$ \\
\hline 0.40 & $-1.616^{\star}(0.00)$ & $-3.290^{*}(0.00)$ & $-3.313^{\star}(0.02)$ & $-3.853^{\star}(0.00)$ & $-6.712^{\star}(0.00)$ & $-3.379^{*}(0.00)$ \\
\hline 0.45 & $-2.242(0.21)$ & $-3.310^{*}(0.00)$ & $-3.215^{*}(0.02)$ & $-3.890^{*}(0.00)$ & $-5.748^{\star}(0.00)$ & $-3.235^{*}(0.00)$ \\
\hline 0.50 & $-2.193(0.20)$ & $-3.326^{\star}(0.00)$ & $-3.283^{\star}(0.03)$ & $-3.953^{\star}(0.00)$ & $-6.681^{\star}(0.00)$ & $-3.140^{*}(0.00)$ \\
\hline 0.55 & $-1.903^{\star}(0.00)$ & $-3.375^{\star}(0.00)$ & $-2.405^{\star}(0.00)$ & $-4.037^{\star}(0.00)$ & $-6.649^{*}(0.00)$ & $-3.227^{\star}(0.00)$ \\
\hline 0.60 & $-1.849^{\star}(0.00)$ & $-3.402^{\star}(0.00)$ & $-2.437^{\star}(0.00)$ & $-4.117^{\star}(0.00)$ & $-6.465^{\star}(0.00)$ & $-3.355^{\star}(0.00)$ \\
\hline 0.65 & $-1.774^{\star}(0.00)$ & $-3.544^{\star}(0.00)$ & $-2.679^{\star}(0.00)$ & $-4.072^{\star}(0.00)$ & $-6.242^{\star}(0.00)$ & $-3.567^{\star}(0.00)$ \\
\hline 0.70 & $-1.848^{\star}(0.00)$ & $-3.589^{\star}(0.00)$ & $-2.800^{*}(0.00)$ & $-3.937^{\star}(0.00)$ & $-6.055^{\star}(0.00)$ & $-3.671^{\star}(0.00)$ \\
\hline 0.75 & $-1.888^{\star}(0.00)$ & $-3.753^{\star}(0.00)$ & $-3.158^{\star}(0.00)$ & $-3.879^{\star}(0.00)$ & $-6.478^{\star}(0.00)$ & $-4.065^{\star}(0.00)$ \\
\hline 0.80 & $-2.036^{\star}(0.00)$ & $-3.900 *(0.00)$ & $-3.412^{\star}(0.00)$ & $-3.821^{\star}(0.00)$ & $-6.584^{\star}(0.00)$ & $-4.117^{\star}(0.00)$ \\
\hline 0.85 & $-2.320^{*}(0.00)$ & $-3.956^{\star}(0.00)$ & $-3.583^{\star}(0.00)$ & $-3.835^{\star}(0.00)$ & $-6.607^{\star}(0.00)$ & $-4.361^{\star}(0.00)$ \\
\hline 0.90 & $-2.329^{*}(0.00)$ & $-3.951^{\star}(0.00)$ & $-3.699^{*}(0.00)$ & $-3.606^{\star}(0.00)$ & $-6.969^{*}(0.00)$ & $-4.514^{\star}(0.00)$ \\
\hline 0.95 & $-3.057^{\star}(0.00)$ & $-2.715^{\star}(0.00)$ & $-4.198^{*}(0.00)$ & $-3.370^{*}(0.00)$ & $-4.280^{*}(0.01)$ & $-4.344^{\star}(0.00)$ \\
\hline
\end{tabular}

26 farklı bankanın her biri için dikkate alınan 19 farklı kantil değerinden oluşan toplam 114 durum içerisinde hepsi AKBNK için olmak üzere sadece 3 durumda katsayılar istatistiki olarak anlamlı çıkmamaktadır. 
Tablo 4. Uzun Vadeli Faiz Oranı Riski için Kantil Regresyon Sonuçları

\begin{tabular}{|c|c|c|c|c|c|c|}
\hline$\tau$ & AKBNK & ISBNK & YPKBNK & GRNBNK & HLKBNK & VKFBNK \\
\hline 0.05 & $-3.854^{\star}(0.01)$ & $-3.800^{*}(0.00)$ & $-4.575^{\star}(0.00)$ & $-4.904^{*}(0.00)$ & $-4.715^{\star}(0.00)$ & $-5.076^{\star}(0.00)$ \\
\hline 0.10 & $-3.787^{*}(0.01)$ & $-4.281^{\star}(0.00)$ & $-6.181^{*}(0.00)$ & $-5.198^{\star}(0.00)$ & $-4.825^{\star}(0.00)$ & $-4.814^{\star}(0.00)$ \\
\hline 0.15 & $-4.381^{*}(0.00)$ & $-4.555^{\star}(0.00)$ & $-6.229^{*}(0.00)$ & $-5.44^{\star}(0.00)$ & $-4.845^{\star}(0.00)$ & $-5.120^{\star}(0.00)$ \\
\hline 0.20 & $-4.685^{*}(0.00)$ & $-4.636^{*}(0.00)$ & $-6.278^{\star}(0.00)$ & $-5.286^{*}(0.00)$ & $-5.055^{*}(0.00)$ & $-5.148^{\star}(0.00)$ \\
\hline 0.25 & $-4.318^{\star}(0.00)$ & $-4.833^{\star}(0.00)$ & $-5.807^{*}(0.00)$ & $-5.524^{\star}(0.00)$ & $-5.549^{\star}(0.00)$ & $-4.844^{\star}(0.00)$ \\
\hline 0.30 & $-3.974^{\star}(0.00)$ & $-4.776^{\star}(0.00)$ & $-4.565^{\star}(0.00)$ & $-5.320^{\star}(0.00)$ & $-4.834^{*}(0.00)$ & $-5.170^{\star}(0.00)$ \\
\hline 0.35 & $-3.532^{\star}(0.01)$ & $-5.152^{\star}(0.00)$ & $-4.533^{\star}(0.00)$ & $-4.783^{\star}(0.00)$ & $-5.171^{*}(0.00)$ & $-5.330^{*}(0.00)$ \\
\hline 0.40 & $-4.132^{\star}(0.00)$ & $-5.443^{\star}(0.00)$ & $-4.765^{\star}(0.00)$ & $-4.855^{\star}(0.00)$ & $-6.765^{\star}(0.00)$ & $-4.993^{\star}(0.00)$ \\
\hline 0.45 & $-4.365^{\star}(0.00)$ & $-5.196^{\star}(0.00)$ & $-4.919^{\star}(0.00)$ & $-5.127^{\star}(0.00)$ & $-6.706^{\star}(0.00)$ & $-5.104^{\star}(0.00)$ \\
\hline 0.50 & $-4.207^{\star}(0.00)$ & $-5.236^{\star}(0.00)$ & $-4.835^{\star}(0.00)$ & $-4.396^{\star}(0.00)$ & $-6.346^{\star}(0.00)$ & $-5.122^{\star}(0.00)$ \\
\hline 0.55 & $-4.322^{\star}(0.00)$ & $-5.345^{\star}(0.00)$ & $-5.100^{*}(0.00)$ & $-4.572^{\star}(0.00)$ & $-6.377^{\star}(0.00)$ & $-5.019^{\star}(0.00)$ \\
\hline 0.60 & $-4.892^{\star}(0.00)$ & $-4.729^{\star}(0.01)$ & $-5.007^{\star}(0.00)$ & $-4.768^{\star}(0.00)$ & $-6.136^{*}(0.00)$ & $-5.354^{\star}(0.00)$ \\
\hline 0.65 & $-4.668^{\star}(0.00)$ & $-4.341^{*}(0.00)$ & $-4.979^{*}(0.00)$ & $-5.025^{\star}(0.00)$ & $-6.183^{\star}(0.00)$ & $-5.531^{\star}(0.00)$ \\
\hline 0.70 & $-4.658^{\star}(0.00)$ & $-4.516^{\star}(0.01)$ & $-4.799^{*}(0.00)$ & $-5.233^{*}(0.00)$ & $-5.905^{\star}(0.00)$ & $-5.296^{\star}(0.00)$ \\
\hline 0.75 & $-4.426^{\star}(0.00)$ & $-4.133^{*}(0.00)$ & $-5.144^{\star}(0.00)$ & $-5.124^{\star}(0.00)$ & $-6.121^{*}(0.00)$ & $-6.547^{\star}(0.00)$ \\
\hline 0.80 & $-4.161^{\star}(0.00)$ & $-4.774^{\star}(0.01)$ & $-5.854^{*}(0.00)$ & $-5.007^{\star}(0.00)$ & $-6.021^{*}(0.00)$ & $-6.048^{\star}(0.00)$ \\
\hline 0.85 & $-4.003^{\star}(0.00)$ & $-5.418^{\star}(0.00)$ & $-6.041^{*}(0.00)$ & $-5.482^{\star}(0.00)$ & $-6.168^{*}(0.00)$ & $-6.160^{*}(0.00)$ \\
\hline 0.90 & $-4.192^{\star}(0.00)$ & $-4.273^{\star}(0.00)$ & $-4.641^{*}(0.00)$ & $-5.466^{\star}(0.00)$ & $-5.046^{\star}(0.00)$ & $-5.874^{\star}(0.00)$ \\
\hline 0.95 & $-3.939^{*}(0.00)$ & $-4.499^{\star}(0.00)$ & $-4.493^{\star}(0.00)$ & $-5.482^{\star}(0.00)$ & $-5.967^{*}(0.00)$ & $-6.339^{*}(0.00)$ \\
\hline
\end{tabular}

\section{I. Faiz Oranı Riski Katsayılarının Kantiller Arasında Değişip Değişmediğinin İncelenmesi}

Kantil regresyon analizlerinde önemli olan noktalardan biri de her bir banka için farklı kantiller dikkate alınarak hesaplanan eğim parametrelerinin yani beta katsayıları ve faiz oranı riski katsayılarının kantiller arasında değişip değiş̧mediğinin incelenmesidir. Bu amaçla genel olarak literatürde Koenker ve Bassett (1982) testi kullanılmaktadır. Bu test yardımı ile örneğin 0.05. kantil dikkate alınarak hesaplanan eğim parametrelerinin 0.50. kantil dikkate alınarak hesaplanan eğim parametrelerinden farklı olup olmadığı sınanabilmektedir. Böylece, her bir banka için farklı kantiller dikkate alındığında faiz oranı riskinin bankalar üzerindeki etkisinin istatistiki olarak anlamlı bir şekilde farklılaşıp farklılaşmadığ incelenebilmektedir. Bu amaçla da literatürde genelde çok düşük kantiller ile ortanca kantiller, çok düşük kantiller ile çok yüksek kantiller ve ortanca kantiller ile çok yüksek kantiller arasında bir fark olup olmadığının sınandığı görülmektedir (Chevapatrakul, 2014, s.125; Kang ve Liu, 2014, s.359; Hammoudeh vd., 2014, s.205).

Bu çalı̧̧mada da benzer bir yöntem izlenmiş ve bu kapsamda elde edilen Koenker ve Bassett (1982) test sonuçları Tablo 5 ve Tablo 6'da (EK I'de) sunulmuştur. Test sonuçlarının iki ayrı tabloda gösterilme nedeni ise bu testin hem modeldeki tüm eğim parametrelerinin birlikte bir kantilden diğerine değişip değişmediği sonucunu rapor etmesi hem de her bir eğim parametresinin tekil olarak değişip değişmediğinin incelenmesine imkan vermesidir. Literatüre bakıldığında çalışmanın 
amacına bağlı olarak her iki yöntemden de yararlanıldığı görülmektedir. Örneğin, Fattouh, Scaramozzino ve Harris (2005, s.246) çalışmalarında toplu sınama sonuçlarına odaklanırken Sula (2011, s.772) çalışmasında tekil sınama sonuçlarına yer vermiştir. Bu çalışmanın konusu itibariyle önemli olan nokta faiz oranı riskinin incelenmesi olduğundan bu çalışmada da tekil sınama sonuçları üzerinde durulmuştur ${ }^{3}$. Ayrıca, kısa ve uzun vadeli faiz oranı riski katsayılarının kantiller arasındaki değişimini gösteren grafikler de Grafik 1 ve 2'de sunulmuştur.

Öncelikle kısa vadeli faiz oranı riskini için kısaca toplu sınama sonuçları incelendiğinde (EK I Tablo 6) tüm bankalar için en az bir kez eğim parametrelerinin toplu bir şekilde kantiller arasında istatistiki olarak anlamlı bir şekilde değiştiği anlaşılmaktadır. Uzun vadeli faiz oranı riski sonuçlarına bakıldığında da ISBNK dışındaki tüm bankalar için eğim parametrelerinin en az bir kez kantiller arasında değiştiği anlaşılmaktadır. Tekil sınama sonuçlarına gelince (Tablo 5) öncelikle kısa vadeli faiz oranı riski için elde edilen sonuçlar incelendiğinde AKBNK ve HLKBNK bankalarının kısa vadeli faiz oranı riski duyarlılıklarının kantiller arasında istatistiki olarak anlamlı bir şekilde değişmediği anlaşılmaktadır. Diğer bankalar içinse tersi bir durumun söz konusu olduğu ifade edilebilir. Bir diğer ifade ile kalan bankaların faiz riski duyarlılıklarının odaklanılan bölgeye bağlı olarak farklılık gösterdiği anlaşılmaktadır. Örneğin ISBNK'ye bakıldığında 0.05 . kantil için elde edilen eğim parametresinin 0.50. kantilden, 0.10. kantil için elde edilen eğim parametresinin 0.90. kantilden ve 0.20. kantil için elde edilen eğim parametresinin de 0.80 . kantilden farklı olduğu anlaşılmaktadır. Dolayısıyla, çalışma kapsamındaki tüm bankaların kısa vadeli faiz oranı riskine duyarlı olduğu, fakat bu bankalardan AKBNK ve HLKBNK'nin hisse senedi dağılımlarının farklı bölgelerine odaklanılmasına rağmen kısa vadeli faiz oranı riski duyarlılıklarının değişmediği, yani kısa vadeli faiz oranı riski açısından tek tip bir ilişki yapısının söz konusu olduğu ifade edilebilir. ISBNK, GRNBNK, YPKBNK ve VKFBNK içinse ise kısa vadeli faiz oranı riski duyarlılıklarının daha değişken bir yapı sergilediği anlaşılmaktadır. Uzun vadeli faiz oranı riski sonuçlarına gelince, farklı dağılım bölgeleri dikkate alındığında bankaların uzun vadeli faiz oranı riski duyarlılıklarının istatistiki olarak anlamlı bir şekilde değişmediği görülmektedir. Nitekim kısa ve uzun vadeli faiz oranı riski katsayılarının kantiller arasındaki değişimini gösteren Grafik 1 ve 2'de sunulan değerler de test istatistiklerine bağlı olarak yapılan bu analizleri doğrulamaktadır.

3 Nitekim, toplu sınamada elde edilen bulgular eğim parametrelerinin birlikte dikkate alınması durumunda bunların değişip değişmediğini rapor ederken aslında değişim sadece tek bir eğim parametresindeki değişimin istatistiki olarak çok güçlü olmasından kaynaklanmış olabilir. Bir diğer ifadeyle, örneğin aslında faiz oranı riski değişmezken bankanın sadece beta katsayısı değiştiği için toplu sınama sonuçları eğim parametrelerinin değiştiği sonucuna işaret edebilir. Bu vb. durumlar da tekil sınama sonuçlarının önemini artırmaktadır. 
Tablo 5. Eğim Parametrelerinin Kantiller Arasında Değişip Değişmediğinin Sınanması (Tekil Sınama)

\begin{tabular}{|c|c|c|c|c|c|c|}
\hline & AKBNK & ISBNK & YPKBNK & GRNBNK & HLKBNK & VKFBNK \\
\hline \multicolumn{7}{|c|}{ Kısa vadeli faiz oranı } \\
\hline \multicolumn{7}{|l|}{ Beta katsayısı } \\
\hline Ho: $0.05=0.95$ & 0.434 & $0.053^{* *}$ & 0.203 & 0.509 & $0.001^{*}$ & 0.149 \\
\hline Ho: $0.10=0.90$ & 0.984 & 0.400 & 0.347 & 0.120 & 0.273 & 0.550 \\
\hline Но: $0.20=0.80$ & 0.905 & 0.367 & 0.105 & $0.017^{\star}$ & 0.200 & 0.516 \\
\hline Ho:0.15=0.85 & 0.665 & 0.668 & $0.067^{\star *}$ & 0.645 & $0.038^{*}$ & 0.148 \\
\hline Но: $0.30=0.70$ & 0.925 & $0.081^{\star *}$ & 0.347 & 0.242 & 0.664 & 0.948 \\
\hline Но: $0.50=0.95$ & $0.033^{*}$ & 0.223 & $0.056^{* *}$ & $0.027^{*}$ & $0.012^{*}$ & $0.022^{*}$ \\
\hline Нo: $0.05=0.50$ & 0.486 & 0.206 & 0.963 & 0.792 & 0.273 & 0.723 \\
\hline \multicolumn{7}{|c|}{ Faiz oranı riski katsayısı } \\
\hline Ho: $0.05=0.95$ & 0.656 & 0.834 & $0.084^{* \star}$ & 0.678 & 0.945 & 0.252 \\
\hline Ho: $0.10=0.90$ & 0.650 & $0.002^{*}$ & 0.749 & 0.441 & 0.562 & $0.001^{*}$ \\
\hline Ho: $0.20=0.80$ & 0.799 & $0.069^{* *}$ & 0.664 & 0.372 & 0.227 & 0.909 \\
\hline Но: $0.15=0.85$ & 0.917 & 0.132 & 0.577 & 0.416 & 0.288 & 0.902 \\
\hline Но: $0.30=0.70$ & 0.514 & 0.367 & 0.952 & 0.406 & 0.337 & 0.839 \\
\hline Ho: $0.50=0.95$ & 0.612 & 0.765 & 0.533 & 0.369 & 0.206 & $0.037^{*}$ \\
\hline Ho: $0.05=0.50$ & 0.812 & $0.039^{\star}$ & 0.532 & $0.088^{* *}$ & 0.114 & 0.936 \\
\hline \multicolumn{7}{|c|}{ Uzun vadeli faiz oranı } \\
\hline \multicolumn{7}{|l|}{ Beta katsayısı } \\
\hline Но: $0.05=0.95$ & 0.501 & $0.069^{* *}$ & $0.007^{\star}$ & 0.480 & $0.017^{\star}$ & 0.163 \\
\hline Нo: $0.10=0.90$ & 0.917 & 0.799 & $0.016^{*}$ & 0.227 & 0.584 & 0.319 \\
\hline Но: $0.20=0.80$ & 0.818 & 0.939 & $0.037^{\star}$ & 0.164 & $0.045^{\star}$ & 0.885 \\
\hline Но: $0.15=0.85$ & 0.943 & 0.726 & $0.035^{\star}$ & 0.308 & 0.117 & 0.681 \\
\hline Но: $0.30=0.70$ & 0.605 & 0.145 & 0.296 & 0.917 & 0.625 & 0.986 \\
\hline Но: $0.50=0.95$ & $0.009^{*}$ & 0.110 & $0.000^{*}$ & 0.194 & $0.027^{*}$ & $0.089^{* *}$ \\
\hline Но: $0.05=0.50$ & 0.247 & 0.339 & 0.985 & 0.745 & 0.560 & 0.882 \\
\hline \multicolumn{7}{|c|}{ Faiz oranı riski katsayısı } \\
\hline Но: $0.05=0.95$ & 0.954 & 0.492 & 0.955 & 0.594 & 0.461 & 0.229 \\
\hline Но: $0.10=0.90$ & 0.769 & 0.994 & 0.249 & 0.792 & 0.891 & 0.312 \\
\hline Ho: $0.20=0.80$ & 0.705 & 0.937 & 0.687 & 0.823 & 0.487 & 0.385 \\
\hline Но: $0.15=0.85$ & 0.799 & 0.659 & 0.865 & 0.969 & 0.322 & 0.338 \\
\hline Но: $0.30=0.70$ & 0.613 & 0.861 & 0.792 & 0.945 & 0.416 & 0.897 \\
\hline Но: $0.50=0.95$ & 0.799 & 0.549 & 0.760 & 0.325 & 0.782 & 0.247 \\
\hline Но: $0.05=0.50$ & 0.822 & 0.209 & 0.824 & 0.705 & 0.304 & 0.964 \\
\hline
\end{tabular}

*, **, sırasıyla \% 5 ve \% 10 anlamlllık düzeyini ifade etmektedir. Verilen değerler olasılık değerleridir. 
Grafik I. Kısa Vadeli Faiz Oranı Riski Katsayılarının Kantiller Arasındaki Değişimi AKBNK
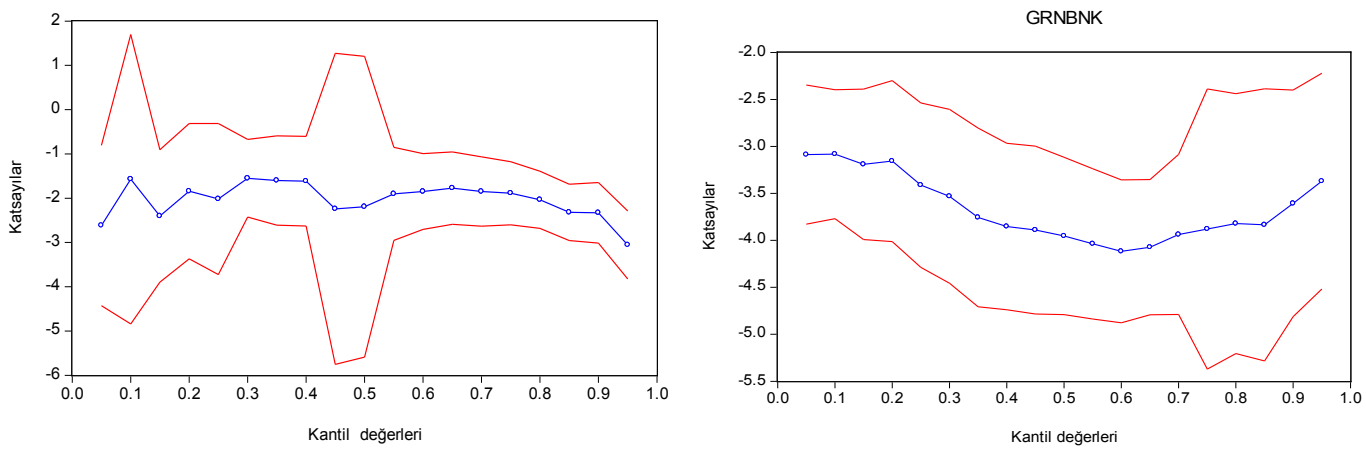

ISBNK
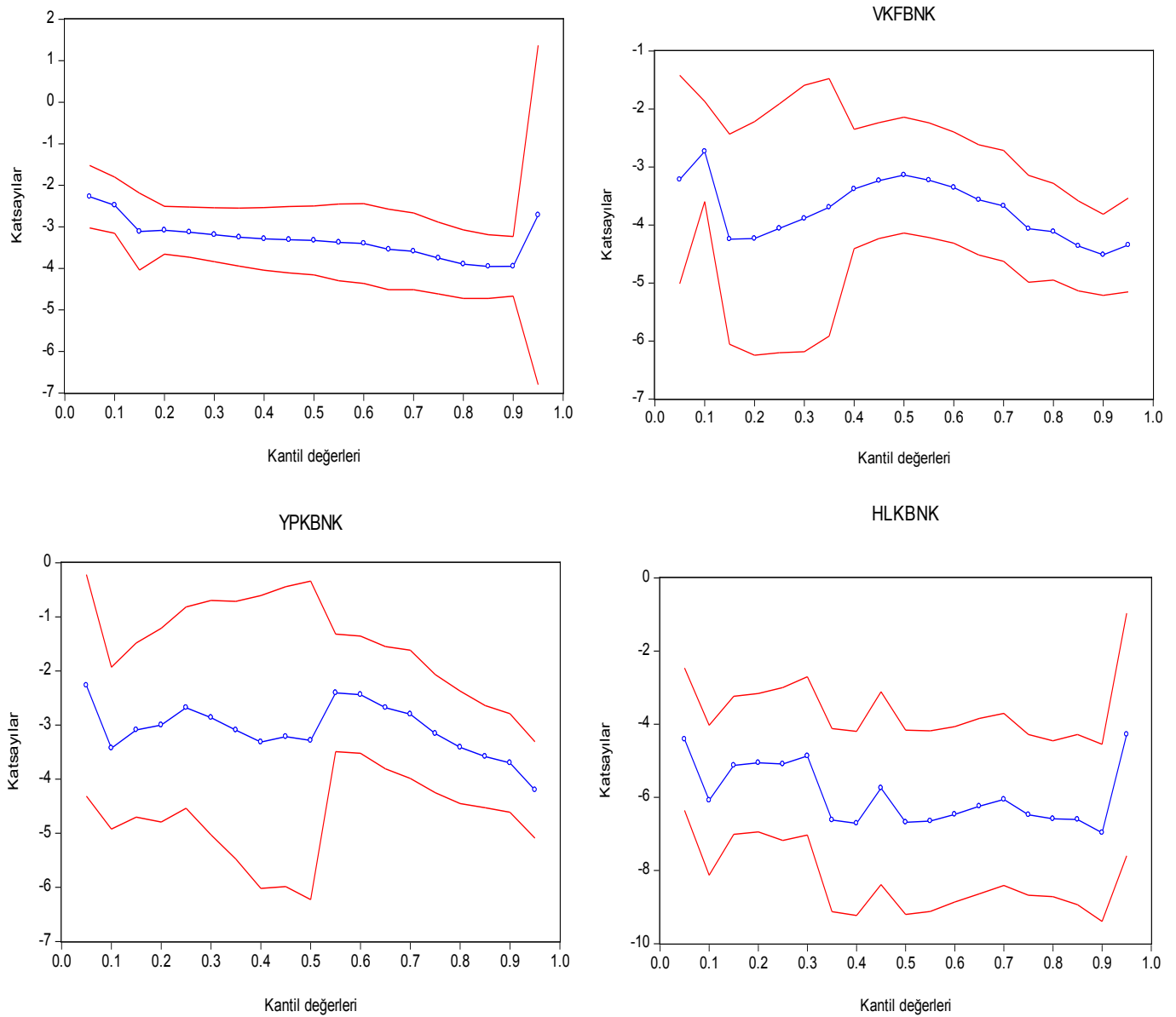

Kırmızı çizgiler \%95 güven aralığını, mavi çizgi ise faiz oranı riski katsayılarının kantiller arasındaki değişimini göstermektedir. 


\section{Grafik 2. Uzun Vadeli Faiz Oranı Riski Katsayılarının Kantiller Arasındaki Değişimi}
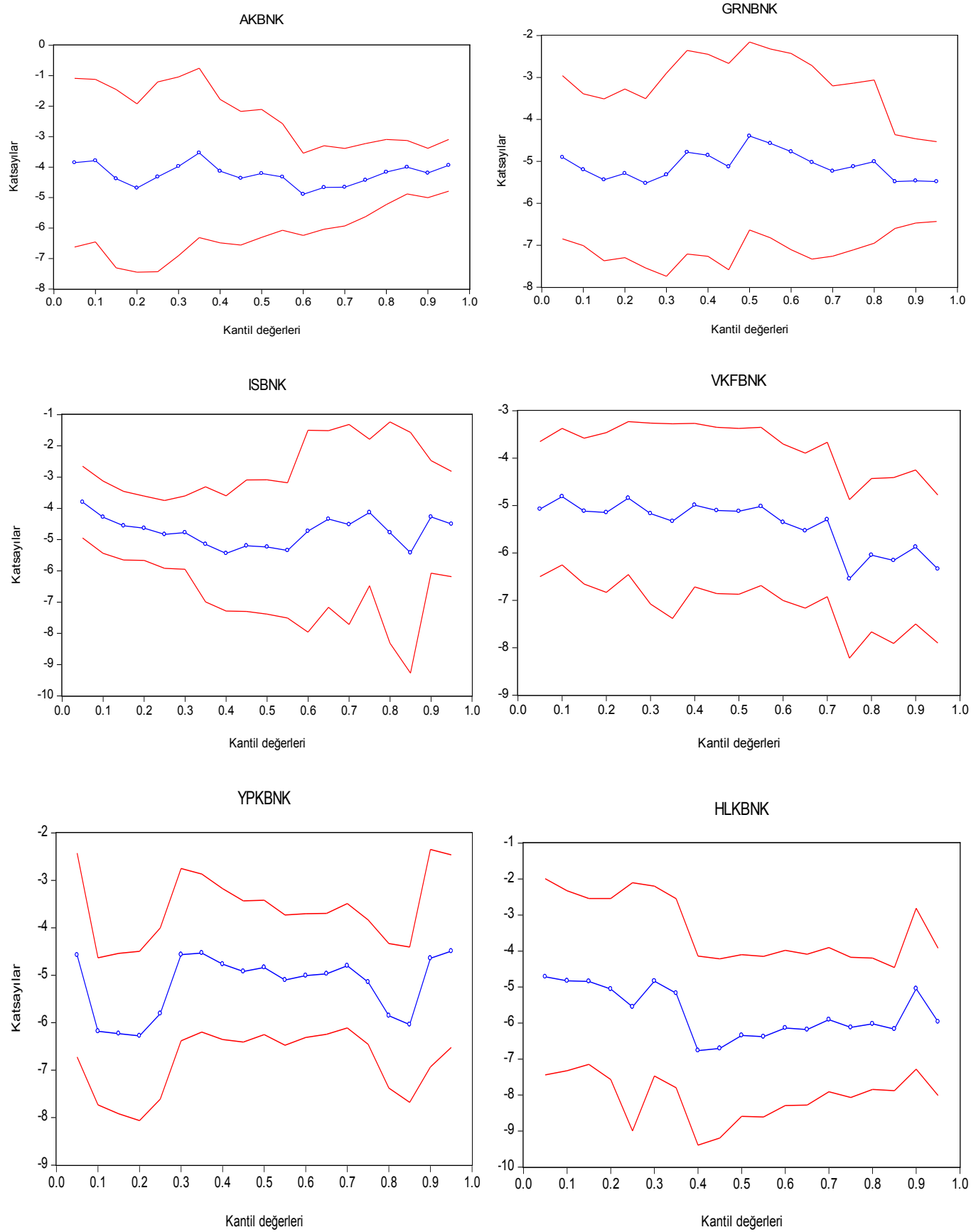

Kırmızı çizgiler \%95 güven aralığını, mavi çizgi ise faiz oranı riski katsayılarının kantiller arasındaki değişimini göstermektedir. 


\section{SONUÇ ve DEĞERLENDIRME}

Son dönemlerde FED ve ECB gibi küresel merkez banklarının para politikaları uygulamaları ve TCMB'nin faiz oranı kararları konusundaki tartışmalar faiz oranlarının bankalar üzerindeki etkisinin incelenmesinin önemini artırmıştır. Bu çalışmada BIST’te işlem gören büyük ölçekli 6 mevduat bankasının kısa ve uzun vadeli faiz oranı riskine duyarlı olup olmadıkları kantil regresyon yöntemi ile incelenmiştir. Böylece, hem standart EKK tahmincilerine göre daha güvenilir sonuçlar elde edilmeye çalışılmış hem de bağımlı değişkenin dağılımının farklı kısımlarının dikkate alınması durumunda faiz oranı riskinin bankalar üzerindeki etkisinin değişip değişmediği incelenebilmiştir. Bulgular inceleme kapsamındaki bankaların hem kısa hem de uzun vadeli faiz oranı riskine karşı duyarlı olduklarına ve her iki faiz oranındaki artışların bankaların hisse senetlerinin değer kaybetmesine yol açtığına işaret etmektedir. Ayrıca, bankaların kısa vadeli faiz oranı riskine nazaran uzun vadeli faiz oranı riskine çok daha duyarlı oldukları belirlenmiştir. Dahası, en yüksek kısa ve uzun vadeli faiz oranı riskini taşıyan bankanın HLKBNK, en düşük kısa ve uzun vadeli faiz oranı riskini taşıyan bankanın ise AKBNK olduğu anlaşılmaktadır.

Hisse senedi getirilerinin dağılımının farklı bölgeleri dikkate alındığında bankaların kısa vadeli faiz oranı riskine olan duyarlılıklarının değişip değişmediğine gelince AKBNK ve HLKBNK bankalarının kısa vadeli faiz oranı riski duyarlılıklarının pek değişmediği diğer bankaların ise, özellikle de ISBNK ve VKFBNK'nin kısa vadeli faiz oranı riski duyarlılıklarının odaklanılan dağılım bölgesine göre büyüklük açısından değiştiği anlaşılmaktadır. Uzun vadeli faiz oranı riski duyarlılığına gelince bulgular bankaların uzun vadeli faiz oranı riski duyarlılıklarının odaklanılan dağılım bölgesine duyarlı olmadığına işaret etmektedir. Dolayısıyla, uzun vadeli faiz oranı riskinin daha az değişken bir yapı sergilediği ifade edilebilir. Ayrıca, bankalar arasında faiz oranlarına duyarlılık açısından ortaya çıkan farklılıklar ise bankaların büyüklükleri, risk yönetim kültürleri, borç kompozisyonları, ortaklık yapıları, bilanço esneklikleri, faize duyarlı aktif ve pasif yapılarındaki farklılıklar gibi nedenlerden kaynaklanmış olabilir.

Çalışma kapsamında elde edilen bu bulgularının bankalar, denetleyici ve düzenleyici kurumlar ve yatırımcılar açısından önemli olduğu düşünülmektedir. Çünkü mevcut bulgular öncelikle faiz oranlarının tartışıldığı bir dönemde kısa ve uzun vadeli faiz oranı riski açısından 6 büyük mevduat bankasının durumunun ne olduğunu ortaya koymaktadır. Fakat bu çalışmadaki analizlerde bankaların faiz oranı riskine duyarlı olmalarına yol açan faktörler üzerinde durulmamıştır. Dolayısıyla, bundan sonraki çalışmalarda bu konunun incelenmesinin sürecin daha bütüncül bir açıdan değerlendirilebilmesi açısından önemli bilgiler sunabileceği düşünülmektedir.

\section{KAYNAKÇA}

AGGARWAL, Raj, JEON, B. Philips ve ZHAO, Xinlei .(2006). Bank Exposure to Interest Rate Risks During Financial Liberalization: Evidence from South Korea. Asia-Pacific Financial Markets, 12, 61-90.

AKELLA, R. Srinivas ve GREENBAUM, I. Stuart .(1992). Innovations in Interest Rates, Duration Transformationa, and Bank Stock Returns. Journal of Money, Credit and Banking, 24 (1), 27-42.

AYSUN, Uluc ve GULDİ, Melanie .(2011). Exchange Rate Exposure: A Nonparametric Approach. Emerging Markets Review, 12, 321-337. 
BAUR, D. Girk .(2013). The Structure and Degree of Dependence: A Quantile Regression Approach. Journal of Banking \& Finance, 37, 786-798.

BERNANKE, S. Ben ve KUTTNER, N., Kenneth .(2005). What Explains The Stock Market's Reaction to Federal Reserve Policy?. Journal of Finance, 60 (3), 1221-1257.

BHARATI, Rakesh., NANISETTY, Prasad ve SO, Jacky .(2006). Dynamic Gap Transformations: Are Banks Asset Transformers or Brokers? or Both ?. The Quarterly Review of Economics and Finance, 46, 36-52.

CHEN, Chieng-Liang, KUAN, Chung-Miang ve LIN, Chu-Chia .(2007). Saving and Housing of Taiwanese Households: New Evidence from Quantile Regression Analysis. Journal of Housing Economics, 16, 102-126.

CHEVAPATRAKUL, Thanaset .(2014). Monetary Environments and Stock Returns Revisited: A Quantile Regression Approach. Economics Letters, 123, 122-126.

CHEVAPATRAKUL, Thanaset .(2015). Monetary Environments and Stock Returns: International Evidence based on the Quantile Regression Technique. International Review of Financial Analysis, 38,83-108.

CHOI, Jay Jongmoo ve PRASAD, Anita Mehra .(1995). Exchange Rate Sensitivity and its Determinants: A Firm and industry Analysis of U.S. Multinational. Financial Management, 24 ( 3), 77-88.

CHUANG, Chia-Chang, KUAN, Chung-Ming ve Lin, Hsin-Yi .(2009). Causality in Quantiles and Dynamic Return-Volume Relations. Journal of Banling \& Finance, 33, 1351-1360.

CINER, Cetin .(2015). Time Variation in Systematic Risk, Returns and Trading Volume: Evidence from Precious Metals Mining Stocks. International Review of Financial Analysis,41,277-283.

CZAJA, Marc-Gregor, SCHOLZ, Hendric ve WILKENS, Marco .(2009). Interest Rate Risk of German Financial Institutions: The Impact Of Level, Slope, and Curvature of the Term Structure. Review of Quantitative Finance and Accounting, 33,1-26.

DINENIS, Elias ve STAIKOURAS, Sotiris, K. (1998). Interest Rate Changes and Common Stock Returns of Financial Institutions: Evidence from the UK. The European Journal of Finance, 4, 113-127.

ELYASIANI, Elyas ve MANSUR, Igbal .(1998). Sensitivity of the Bank Stock Returns Distribution to Changes in the Level and Volatility of Interest Rate: A GARCH-M Model. Journal of Banking \& Finance, 22, 535563.

FAFF, Robert William ve HOWARD, P.F. (1999). Interest Rate Risk of Australian Financial Sector Companies in a Period of Regulatory Change. Pacific-Basin Finance Journal, 7, 83-101.

FATTOUH, Bassam, SCARAMOZZINO, Pasquale ve HARRIS, Laurence .(2005). Capital Structure in South Korea: A Quantile Regressison Approach. Journal of Developments Economics,76, 231-250.

FERRER, Roman, GONZÁLEZ, Cristobal ve SOTO, Gloria M. (2010). Linear and Nonlinear Interest Rate Exposure in Spain. Managerial Finance, 36 (5), 431 - 451.

HAMMOUDEH, Shawkat, NGUYEN, Duc Khuong ve SOUSA, Ricardo, M. (2014). Energy Prices and CO2 Emission Allowance Prices: A QuantileRegression Approach. Energy Policy, 70, 201-206.

KANG, Hsin-Hong ve LIU, Shu-Bing (2014). The Impact of the 2008 Financial Crisis on Housing Prices in China and Taiwan: A Quantile Regression Analysis. Economic Modelling,42, 356-362.

KASMAN, Saadet, VARDAR, Gülin ve TUNÇ, Gökçe .(2011). The Impact of Interest Rate and Exchange Rate Volatility on Banks' Stock Returns and Volatility: Evidence from Turkey. Economic Modelling, 28, 13281334.

KOENKER, Roger ve BASSETT, Gilbert .(1982). Robust Tests for Heteroscedasticity based on Regression Quantiles. Econometrica, 50, 43-61.

KOENKER, Roger ve BASSETT, Gilbert .(1978).Regression Quantiles. Econometrica, 46, 33-50.

KORKEAMÄKI, Timo .(2014). Interest Rate Sensitivity of the European Stock Markets before and after the Euro Introduction. Journal of International Financial Markets, Institutions \& Money, 21, 811- 831. 
LEE, Bong Soo ve LI, Ming-Yuan Leon .(2012). Diversification and Risk-Adjusted Performance: A Quantile Regression Approach. Journal of Banking \& Finance, 36, 2157-2173.

LEE, Chien-Chiang ve ZENG, Jhih Hong .(2011). The Impact of Oil Price Shocks on Stock Market Activities:Asymmetric Effect with Quantile Regression. Mathematics and Cumputers in Simulation, 81, 1910-1920.

MOUNA, Aloui ve ANIS, M. Jarboui .(2012). The Impact of Interest Rate and Exchange Rate Volatility on Bank's Returns and Volatility: Evidence from Tunisian. The Journal of Commerce, 5 (3), 1-19.

ÖZÜN, Alper ve ÇİFTER, Atilla .(2006). Bankaların Hisse Senedi Getirilerinde Faiz Oranı Riski: Dalgacıklar Analizi ile Türk Bankacılık Sektörü Üzerine Bir Uygulama. Bankacılar Dergisi, 59,1-15.

PAPADAMOUA, Stephanos ve SIRIOPOULOS, Costas .(2014). Interest Rate Risk and the Creation of the Monetary Policy Committee: Evidence from Banks' and Life Insurance Companies' Stocks in the UK. Journal of Economics and Busines, 71, 45- 67.

PARK, Jin ve CHOI, B. Paul .(2011). Interest Rate Sensitivity of US Property/ Liability Insurer Stock Returns. Managerial Finance, 37 (2), 134 - 150.

SAHA, Asish, SUBRAMANIAN, V., BASU, Sanjay ve MISHRA, A. Kumar .(2009). Networth Exposure to Interest Rate Risk: An Empirical Analysis of Indian Commercial Banks. European Journal of Operational Research, 193, 581-590.

STONE, Bernell K. (1974). Systematic Interest Rate Risk in a Two Index Model of Return. Journal of Financial and Quantitative Analysis, 9 (5), 709-721.

SUKCHAROENSIN, Pariyada (2013). Time-Varying Market, Interest Rate and Exchange Rate Risks of Thai Commercial Banks. Journal of Accountıng and Finance, 9 (1), 25-45.

SULA, Ozan .(2011). Demand for International Reserves in Developing Nations: A Quantile Regression Approach. Journal of International Money and Finance, 30, 764-777.

SWEENEY, Richard J. ve WARGA, Arthur D. (1986). The Pricing of Interest Rate Risk: Evidence from Stock Market. Journal of Finance, 41 (2), 393-410.

VU, Huong, HOLMES, Mark, LIM, S. ve TRAN, Truyen .(2014). Exports and Profitability: A Note from Quantile Regression Approach. Applied Economics Letters, 21 (6), 442-445. 


\section{EK I:}

Tablo 6. Eğim Parametrelerinin Kantiller Arasında Değişip Değişmediğinin Sınanması (Toplu Sınama)

\begin{tabular}{lllllll}
\hline $\begin{array}{l}\text { Kisa vadeli faiz oranı riski } \\
\text { Hipotezler }\end{array}$ & AKBNK & ISBNK & YPKBNK & GRNBNK & HLKBNK & VKFBNK \\
\hline Ho: $0.05=0.95$ & 0.719 & 0.109 & $0.035^{*}$ & 0.786 & $0.005^{*}$ & 0.185 \\
Ho: $0.10=0.90$ & 0.891 & $0.005^{*}$ & 0.598 & 0.259 & 0.504 & $0.004^{*}$ \\
Ho: $0.20=0.80$ & 0.958 & $0.064^{* *}$ & 0.214 & $0.050^{* *}$ & 0.211 & 0.794 \\
Ho: $0.15=0.85$ & 0.911 & 0.306 & 0.128 & 0.674 & $0.075^{* *}$ & 0.349 \\
Ho: $0.30=0.70$ & 0.806 & $0.094^{* *}$ & 0.642 & 0.453 & 0.571 & 0.977 \\
Ho: $0.50=0.95$ & $0.056^{* *}$ & 0.426 & $0.098^{* *}$ & $0.051^{* *}$ & $0.026^{*}$ & $0.015^{*}$ \\
Ho: $0.05=0.50$ & 0.746 & 0.115 & 0.811 & $0.084^{* *}$ & 0.190 & 0.936 \\
Uzun vadeli faiz oranı riski & & & & & \\
Hipotezler & AKBNK & ISBNK & YPKBNK & GRNBNK & HLKBNK & VKFBNK \\
Ho: $0.05=0.95$ & 0.785 & 0.187 & $0.025^{*}$ & 0.754 & $0.049^{* *}$ & 0.208 \\
Ho: $0.10=0.90$ & 0.953 & 0.967 & $0.013^{*}$ & 0.458 & 0.858 & 0.397 \\
Ho: $0.20=0.80$ & 0.922 & 0.993 & $0.074^{* *}$ & 0.314 & $0.061^{* *}$ & 0.680 \\
Ho: $0.15=0.85$ & 0.967 & 0.850 & $0.096^{* *}$ & 0.536 & 0.165 & 0.582 \\
Ho: $0.30=0.70$ & 0.657 & 0.271 & 0.567 & 0.989 & 0.571 & 0.992 \\
Ho: $0.50=0.95$ & $0.022^{*}$ & 0.277 & $0.002^{*}$ & $0.049^{*}$ & $0.086^{* *}$ & $0.075^{* *}$ \\
Ho: $0.05=0.50$ & 0.512 & 0.327 & 0.975 & 0.910 & 0.556 & 0.987 \\
\hline
\end{tabular}

*, **, sırasıyla \% 5 ve \%10 anlamlllık düzeyini ifade etmektedir. Verilen değerler olasıllk değerleridir. 